\title{
Taxation and Budget Reform Commission (TBRC) Statutory Recommendation: Streamlined Sales and Use Tax Agreement ${ }^{1}$
}

Rodney L. Clouser ${ }^{2}$

A series of 16 fact sheets has been written on statutory and constitutional proposals adopted by the Taxation and Budget Reform Commission (TBRC). The publications in this series can be accessed at http://edis.ifas.ufl.edu. Fact sheets FE733 through FE741 address statutory changes and fact sheets FE742 through FE748 address constitutional amendments. These fact sheets should not be considered as an all-inclusive assessment of the statutory or constitutional changes recommended by the Taxation and Budget Reform Commission. Some details of proposed changes may not have been discussed due to space limitations. These fact sheets are not intended as a replacement for personal knowledge about actual or proposed changes but are a guide to inform the public on the issues.

\section{Introduction}

The Taxation and Budget Reform Commission (TBRC) has made statutory recommendations to the Florida Legislature concerning a streamlined sales and use tax agreement. The statutory recommendations are one of two components, the other being a constitutional amendment for the state to petition to become part of a national sales and use tax agreement. The proposed statutory recommendation represents implementing legislation that brings Florida's sales and use tax laws in line with those of other states that are part of the agreement.

\section{TBRC Justification and Summary of the Statutory Recommendation}

Most states (45) have sales and use taxes, with Alaska, Delaware, Montana, New Hampshire, and Oregon being the exception (Federation of Tax Administrators, http://www.taxadmin.org). Sales taxes are collected at the point of sale and then submitted to the state. However, with the development of new technologies and e-commerce, considerable numbers of goods are purchased outside the state to be used in the state. The use tax is considered by many as an inducement to reduce the purchase of goods out-of-state by requiring a consumer to pay a use tax equivalent to the state sales tax. The use tax recovers sales taxes that would be lost when goods are purchased out-of-state. Some

1. This is EDIS document FE737, a publication of the Food and Resource Economics Department, Florida Cooperative Extension Service, Institute of Food and Agricultural Sciences, University of Florida, Gainesville, FL. Published July 2008. Please visit the EDIS website at http://edis.ifas.ufl.edu.

2. Rodney L. Clouser, professor and extension public policy specialist of the Food and Resource Economics Department, Florida Cooperative Extension Service, Institute of Food and Agricultural Sciences, University of Florida, Gainesville, FL.

The Institute of Food and Agricultural Sciences (IFAS) is an Equal Opportunity Institution authorized to provide research, educational information and other services only to individuals and institutions that function with non-discrimination with respect to race, creed, color, religion, age, disability, sex, sexual orientation, marital status, national origin, political opinions or affiliations. U.S. Department of Agriculture, Cooperative Extension Service, University of Florida, IFAS, Florida A. \& M. University Cooperative Extension Program, and Boards of County Commissioners Cooperating. Larry Arrington, Dean 
would argue that use taxes "level the playing field" and eliminate, at least in theory, the competitive advantages of firms that sell goods in states with lower sales taxes than the state where the consumer resides.

The proposed statutory recommendations are detailed and technical in nature, and are embedded throughout a bill in excess of 100 pages. It is beyond the scope of this fact sheet to discuss the definitional and technical aspects of the proposed statutory recommendations. Individuals who want complete details should access the proposed recommendation at http://www.floridatbrc.org/pdf/SR0017.pdf and the staff analysis at http://www.floridatbrc.org/pdf/ SR0017StaffAnalysis.pdf.

\section{Illustrations of Proposed Statutory Changes}

Examples of recommended changes include the following:

- The TBRC recommends repeal of the current sales tax brackets in Florida and adoption of a conventional rounding methodology. Under the suggested rounding methodology, sales and use tax collections will be calculated to the third decimal point and if the third decimal is less than .005 , the tax due will be rounded down, or if equal or greater than .005 , the tax due will be rounded up. Based on billions of dollars of sales, this difference could be very significant.

- Under current Florida law, all juice drinks containing less than $100 \%$ juice are subject to sales tax. To be in conformance with the streamlined sales and use tax agreement, juices that contain less than $100 \%$ juice but more than $50 \%$ juice would be exempt from sales taxes.

- Currently, frozen dairy and non-dairy products, ice cream, and frozen yogurt sold in cones or containers (cups, pints, etc.), and popsicles, frozen fruit bars, etc. are taxable in Florida. Compliance with the streamlined sales and use tax agreement would exempt these items from taxation.
- Other changes were also recommended with respect to certain candies which are currently taxable under Florida law. Changes recommended by the TBRC to become compliant with the streamlined agreement exempts candies that contain flour from taxation. Exemption from taxation would make these goods relatively cheaper than competitive goods.

- Other provisions to become compliant with the agreement as recommended include exemptions for various medical merchandise and for bakery products sold without eating utensils, and amnesty for sellers of goods (to purchasers within the state) who have not been registered in the preceding 12 months, but who do register and agree to collect the taxes.

As mentioned previously, there are many other changes. Those interested in this topic should refer to the proposed legislation drafted by the TBRC and forwarded to the legislature.

\section{Impact of Proposed Statutory Changes}

The proposed statutory changes are expected to ease tax administration issues across states and encourage the collection and remittance of use taxes by states that are part of the streamlined sales and use tax agreement. Most people probably assume this would automatically increase revenue to the state. However, according to the staff analysis, this assumption is not necessarily true. Although no official estimates have been made, similar legislation has been introduced but not passed in a previous session of Florida's legislature. Estimates of the fiscal impact of that previous proposed legislation indicated that state revenue might actually decline. Participation in the sales and use tax agreement would require a change from the bracket system currently used by the state to a rounding methodology used under the streamlined agreement. For example, Florida currently collects 5 cents on the sale of items costing 67 cents, but under the rounding methodology could only collect 4 cents in taxes. It was also projected under the previous analysis that Florida would collect less because of definitional changes related to frozen dairy and non-dairy products, fruit 
juices containing $50 \%$ or more juice, and various medical exemptions. However, definitional changes related to candy and the sale price of other specified goods, including delivery charges, would result in greater tax collections.

\section{Summary}

Although the statutory recommendations have been made by the TBRC, and in some instances with specific dates to become effective, the Florida Legislature and the Governor are not bound to the effective dates or the recommendations. Before these recommendations become law, they require approval of both the Florida Senate and House, and approval by the Governor. Citizens interested in the specific recommendations will need to follow the progress of the issue through the legislative process.

Additionally, there is no time limit for action by the legislature on the TBRC recommendations and they can be introduced in future legislative sessions if not passed during the current session.

\section{References}

Florida Taxation and Budget Reform Commission. 2008. SR0017: a bill to be entitled an act relating to the Streamlined Sales and Use Tax Agreement. TBRC, Tallahassee, FL (April). http://www.floridatbrc.org/pdf/SR0017_final.pdf

Florida Taxation and Budget Reform Commission. 2008. SR 17 Staff Analysis and Economic Impact Statement. TBRC, Tallahassee, FL.

http://www.floridatbrc.org/pdf/

SR0017StaffAnalysis.pdf

Florida Taxation and Budget Reform Commission.2008. Transmittal letter. TBRC, Tallahassee, FL (April). http://www.floridatbrc.org/pdf/ 3_18_08TransmittalLtrSR17.pdf 